\title{
Anthony Di Mascio \\ The Idea of Popular Schooling in Upper Canada: Print Culture, Public Discourse, and the Demand for Education
}

Kingston and Montreal: McGill-Queen's University Press, 2012. 248 pp.

\section{E.A. Heaman \\ McGill University}

The oppressive, top-down state that provoked a lot of good social history once upon a time has been replaced, in recent years, with a state that was constructed to a surprising degree from the bottom up. People demanded a whole range of services that the private sector couldn't provide, ranging from criminal justice to income support to schooling, and their demands for those state services often significantly outpaced what government officials were prepared to supply. People didn't always get the services on the terms that they wanted - and residential schools aimed at coercive assimilation of indigenous children provide the worst example of ironic outcomes - but they entered passionately and hopefully into the conversations about what could or should be public services. Amongst the excellent social history that the discovery of the demand-led state has been provoking is Anthony Di Mascio's new book on The Idea of Popular Schooling in Upper Canada: Print Culture, Public Discourse, and the Demand for Education.

Di Mascio looks for and finds evidence of popular demand for common schools in Upper Canada that considerably pre-dated the legislation creating such schools. Private schools were expensive and their quality was erratic; only state intervention could bring cheap and decent schools to ordinary people across the province. Reformers and newspapermen took up the cry for popular schooling first, around the turn of the century. Conservative elites only began to respond to that demand in the second decade of the nineteenth century, after the War of 1812 convinced them of the need to cultivate a conservative and loyal identity amongst the people. To no small degree, Di Mascio argues, educational policy offered a rare possibility 
of consensus amongst conservatives and reformers. Much of the fascination of the early part of the book is in the perplexity of such conservatives in the face of that public demand, reflecting their disapproval of the very notion of public demand. John Strachan, an ambitious Anglican priest and schoolmaster, generally acknowledged as the ideological centre of Upper Canadian high Toryism, was in the (to him) excruciating position of having to woo popular opinion because, in the absence of popular schooling, ordinary people were sending their children to free American schools. Such schools could provide a good practical education, but not the loyalty and orthodox piety that Strachan yearned to disseminate. Because parents could and did exercise their choice of American schooling, they could effectively remake Upper Canadian politics from the bottom up, without recourse to such extreme measures as shouldering a rifle at Montgomery's tavern.

Di Mascio's account of Tory embarrassment around schooling recalls Jeffrey McNairn's account of Tory embarrassment around critical public debate: ${ }^{1}$ both issues seemed to play to reform purposes by irresistibly appealing to the workings of popular agency. Indeed, Di Mascio consciously models his book upon McNairn's history of deliberative democracy in Upper Canada, including the focus on an emergent print culture. This is an extremely useful and interesting application of McNairn's work in a new area. It puts early Canadian statism into closer dialogue with later Canadian statism: from cross-border shopping for education to "abortion tourism," we see the perennial choice (as described by the earliest advocates of government patronage for Canadian broadcasting): “The state or the States." For, indeed, the public got its education. The convergence of reform and conservative educational projects couldn't happen before the rebellions: politics became too polarized for that to happen (according to an escalating rhetorical logic that Di Mascio examines closely). But the debates powerfully stoked that popular demand, so there could be no turning back to a status quo ante. In the aftermath of the rebellions, Egerton Ryerson successfully built up a new consensus from the ashes of the old.

The Idea of Popular Schooling is a good book but a short one that doesn't quite get to the bottom of all the questions it asks. Because he focuses on the idea of education, Di Mascio doesn't provide many facts or numbers about the actual incidence of schooling and for the early years in particular - crucial to the formulation of the idea - he has to rely on a small number of newspaper articles advocating public schools. Those articles may reflect a would-be intelligentsia rather than "the people" and some discussion of the relationship between the two would be helpful. Whereas McNairn's study of deliberative democracy shows how the idea and the actual performance of public debate formed a kind of feedback loop, Di Mascio tells us very little indeed about the practical side of education. He gives us the sound and fury of people arguing about education but without the concrete experiences that usually drive bottom-up histories. Di Mascio's "people" is closer to an intellectual or even rhetorical construct than to the kind of socially defined category that one might expect in a book that began life as a dissertation supervised by Chad Gaffield, an important social historian. Di Mascio beautifully introduces and frames important new questions about the early development of education in Canada, but to arrive at more 
definitive answers than he can provide here will require him to expand his scope. This reviewer looks forward to his next work with great anticipation.

\section{Notes}

1 Jeffrey L. McNairn, The Capacity to Judge: Public Opinion and Deliberative Democracy in Upper Canada, 1791-1854 (Toronto: UTP, 2000). 